\title{
Identification Of Palm Using Otsu Method and Mathematical Morphology to Open House Doors \\ Identifikasi Telapak Tangan Menggunakan Metode Otsu Dan Morphology Matematika Untuk Membuka Pintu Rumah
}

\author{
Mahdiasa Sholihin ${ }^{1}$, M. Arif ${ }^{2}$, M.Hafiz Alfansury ${ }^{3}$, Nindi Misyahdul Yuzi ${ }^{4}$ Sumijan ${ }^{5}$ \\ 1,2,3,4,5 Fakultas Ilmu Komputer Universitas Putra Indonesia "YPTK" Padang, Indonesia \\ 1․mahdibocah@gmail.com,${ }^{2}$ muhammadarif280997@gmail.com, ${ }^{3}$ muhammad.hafiz0690@gmail.com, \\ ${ }^{4}$ nindimisyahdulyuzi@gmail.com, ${ }^{5}$ soe@upiyptk.org
}

\begin{abstract}
Abstrak
Sistem biometrika merupakan teknologi pengenalan individu dengan menggunakan bagian tubuh atau perilaku manusia.Telapak tangan dan sidik jari, masing-masing contoh biometrika berdasarkan bagian tubuh dan tingkah laku manusia. Pencocokan citra adalah suatu cara untuk mengidentifikasi citra. Penelitian ini menggunakan teknologi biometrik yaitu sistem yang melakukan pencocokan citra berdasarkan bagian tubuh manusia dengan mencocokkan antara citra uji yang diterima dengan citra latihan yang terdapat dalam database.Citra yang digunakan adalah telapak tangan.Penggunaan telapak tangan dikarenakan telapak tangan memiliki karakteristik yang unik, sulit dipalsukan dan cenderung stabil. Sample citra telapak tangan yang akan digunakan ada 10 buah sample yang akan dioleh menggunakan metode Otsu dan metode Morphology Matematika, yang sebelumnya telah difilter menggunakan filter median dan diubeh menjadi grayscale. Dari 10 sample yang berbeda menunjukan hasil yang berbeda-beda dengan rata-rata tingkat kemiripan mencapai $96.28 \%$, metode tersebut membuktikan bahwa ruas-ruas telapak tangan merupakan suatu ciri khas yang dimiliki oleh setiap orang, dan hal tersebut juga membuktikan bahwa telapak tangan juga bisa dijadikan sebagai salah satu alternatif untuk melindungi privasi, bukan hanya sidik jari saja untuk pengamanan rumah.
\end{abstract}

Kata kunci:Morphology Matematika,Citra Telapak Tangan, Otsu, Median

\begin{abstract}
The biometrics system is an individual recognition technology using human body parts or behavior. Palm and fingerprints, each biometrics example based on body parts and human behavior. Image matching is a way to identify images. This research uses biometric technology, a system that performs image matching based on human body parts by matching test images received with training images contained in a database. The image used is the palm of the hand. The use of the palm because the palm has unique characteristics, is difficult to fake and tends to be stable. There are 10 samples of the palm image that will be used using the Otsu method and the Math Morphology method, which were previously filtered using a median filter and turned into grayscale. From 10 different samples showing different results with an average similarity level of $96.28 \%$, the method proves that the palm joints are a characteristic that is owned by everyone, and it also proves that the palm can also used as an alternative to protect privacy, not just fingerprints for home security.
\end{abstract}

Keywords: Morphology of Mathematics, Palm Image, Otsu, Median 